\title{
Chemical and Phytochemical Profile of Some Uncommon Green Leafy Vegetables Consumed In South West, Nigeria
}

\author{
"Oduse Kayode A., Idowu Micheal A. and Adegbite Adefolawe A. \\ Department of Food Science and Technology. Federal University of Agriculture Abeokuta. PMB 2240, \\ Abeokuta, Nigeria.
}

\begin{abstract}
Green Leafy Vegetables (GLV) plays a vital role in the food culture of Nigerians and Africans as a whole. In this study, eleven green leafy vegetables not commonly consumed from south west Nigeria were analysed for proximate composition, mineral compositions and phytochemicals composition (Tannins, flavonoids and alkaloids). The green leafy vegetables analysed with corresponding local names were Launea taraxacifolia "Yanrin", Struchium sparaganophora "Ewuro Odo", Cnidoscolus aconitifolina "Iyan Ipaja", Vernonia amygdalina "Ewuro", Solanum nigrum "Odu", Crassocephalum crepidioides "Ebolo", Ocimum gratissimum "Efirin", Manihot esculenta "Ewe ege", Colocassia esulenta "Ewe koko", Cerathoteca sesamoides "Ekuku" and Bidens pinnata "Abere oloko". There was a significant difference $(P<0.05)$ among the samples in chemical and phytochemical composition. The percentage moisture, protein, ether extract, ash, crude fibre, and carbohydrate content range from 78.60 to $88.47 \%, 1.76$ to $3.36 \%, 0.20$ to $2.93 \%, 1.73$ to $4.43 \%, 2.56$ to $3.73 \%$ and 2.93 to $12.33 \%$ respectively. The calcium, Iron, magnesium and phosphate also range from 87.67 to $187.33 \mathrm{mg} / \mathrm{kg}, 2.50$ to $7.50 \mathrm{mg} / \mathrm{kg}$, 2.33 to $5.23 \mathrm{mg} / \mathrm{kg}$ and 33.66 to $115.67 \mathrm{mg} / \mathrm{kg}$ respectively. The phytochemicals determined are: Tannin, total alkaloid and flavonoid with values 8.33 to $39.00 \mathrm{mg} / \mathrm{kg}$, 6.50 to $13.83 \mathrm{mg} / \mathrm{kg}$ and 12.53 to $35.33 \mathrm{mg} / \mathrm{kg}$ respectively. The data suggests that the eleven leafy vegetables analysed have both nutritional and phytochemical potentials.
\end{abstract}

Keywords: Leafy vegetables, phytochemicals, chemical, composition, Nigeria.

\section{Introduction}

In Nigeria, vegetables are mostly consumed as part of a meal rather than as a whole meal. These herbaceous plants have different tastes and characteristics ranging from soft to hard, tasteless, aromatic and bitterness [1]. Green leafy vegetables play a very important role in the food culture of Africans [2].

The composition of nutritients is different in various leafy vegetables and these are due to difference in climate, soil, postharvest handling and the use of fertilizer [3,4]. A previous study by Okafor reported that vegetables are not only cheap sources of nutrients but are also common sources [5].

Fruits and vegetables are the greatest sources of phytochemicals and facts have emerged that some antinutritional content of these vegetables have potentials in reducing some diseases in man [6, 7]. Some of these diseases include high blood pressure, heart attack, stroke and other cardiovascular diseases [7]. These antinutrients or phytochemicals carry out their healing activities by combining with vitamins or with other nutrients [8]. Information is however scanty on the nutritional and phytochemical contents of these leafy vegetables. Hence, there is need to discover the potential of our local vegetables in relation to the provision of basic nutrients and phytochemicals, as this will help provide vital data for food processors, nutritionist, dieticians, as well as the consumers for the selection of these green leafy vegetables beyond south west of Nigeria.

So, this work focuses on making a profile of the chemical and phytochemical composition of the selected Green Leafy Vegetables uncommonly consumed in South West Nigeria with the aim of increasing the nutritional awareness of these vegetables.

\subsection{Materials}

\section{Materials And Methods}

Eleven fresh Green Leafy vegetables were procured from different local markets in and around south west of Nigeria. They were identified at the College of Plant Science, Federal University of Agriculture Abeokuta. Nigeria (Table 1).

\subsection{Sample Preparation}

The Green leafy vegetables (GLV) were inspected for unwanted materials such as stones and pebbles. Then properly washed before proceeding to the individual analysis. 


\begin{tabular}{ll} 
Table1: Scientific names of the Green Leafy Vegetables analysed \\
\hline Scientific Name & Local name (Yoruba) \\
\hline Launea taraxacifolia & "Yanrin" \\
Struchium sparaganophora & "Ewuro-odo" \\
Cnidoscolus aconitifolina & "Iyana-Ipaja" \\
Vernonia amygdalina & "Ewuro" \\
Solanum nigrum & "Odu" \\
Crassocephalum crepidioides & "Ebolo" \\
Ocimum gratissimum & "Efirin" \\
Manihot esculenta & "Ewe ege" \\
Colocassia esulenta & "Ewe koko" \\
Cerathoteca sesamoides & "Ekuku" \\
Bidens pinnata & "Abere oloko" \\
\hline
\end{tabular}

\subsection{Determination of Chemical Composition}

The percentage moisture, protein, ether extract, Ash and Crude fibre content were analysed according to the method of AOAC 2006 [9]. While the percentage carbohydrate was estimated by difference.

\section{$\%$ Carbohydrate $=100-(\%$ M. C + \% E. extract + \% crude fiber + \% protein + \% Ash $)$}

The minerals: calcium, iron, magnesium and phosphorous were analysed by Atomic Absorption Spectrophotometer (AAS) Buck 211 Model USA using the method described by AOAC 2006 [9]. Each element (calcium, iron, magnesium and phosphorous) were then calculated as follows;

$$
\text { Conc. }(\mathrm{mg} / 100 \mathrm{~g})=\frac{\text { standard concentration } \mathrm{x} \text { sample absorbance } \mathrm{x} 100}{\text { standard absorbance } \mathrm{x} \text { weight of sample }}
$$

\subsection{Phytochemical Determination}

The tannin, total alkaloid and flavonoid were determined using the method described by AOAC 2006

[9].

\subsection{Statistical Analysis}

Triplicate determination of each analyses were made and means calculated. Analysis of variance (ANOVA) was conducted to determine significant difference, while means were separated using Duncan Multiple Range Test (DMRT).

\section{Results}

The data generated for the proximate, mineral and phytochemical composition of the uncommonly consumed green leafy vegetables in South west Nigeria is presented on (Table 2, 3 and 4). Solanum nigrum had the highest moisture content of $88.47 \%$, while Vernonia amygdalina had the lowest moisture content $(78.6 \%)$ (Fig. 1). The protein content range from 1.76 to $3.36 \%$ (Table 2, Fig. 2). Ether extract was highest in Ocimum gratissimum $(2.93 \%)$. This value differs widely from the ether extract content of other leafy vegetables with values ranging from 0.20 to $0.50 \%$. Ash content of the leafy vegetables was highest in Solanum nigrum (4.43\%) and this is about two folds of the other leafy vegetables (Table 2). Vernonia amygdalina and Launea taraxacifolia had the highest crude fibre and carbohydrate content of $3.60 \%$ and $12.33 \%$ respectively, while Solanum nigrum had both the least content of crude fibre and carbohydrate content of $2.56 \%$ and $2.93 \%$ respectively.

Table 2.0 Mean values of the Proximate composition of leafy vegetables analysed

\begin{tabular}{lcccccc}
\hline Samples & Moisture \% & Protein \% & E. Extract \% & Ash\% & C. fibre \% & Carbohydrate \% \\
\hline L. taraxacifolia & $79.77^{\mathrm{i}}$ & $3.36^{\mathrm{a}}$ & $0.30^{\mathrm{e}}$ & $1.90^{\mathrm{f}}$ & $3.56^{\mathrm{b}}$ & $11.43^{\mathrm{b}}$ \\
S. sparaganophora & $81.30^{\mathrm{h}}$ & $2.36^{\mathrm{g}}$ & $0.46^{\mathrm{bc}}$ & $2.20^{\mathrm{d}}$ & $2.90^{\mathrm{f}}$ & $10.77^{\mathrm{c}}$ \\
C. aconitifolina & $87.47^{\mathrm{b}}$ & $2.96^{\mathrm{c}}$ & $0.20^{\mathrm{f}}$ & $1.73^{\mathrm{g}}$ & $3.03^{\mathrm{e}}$ & $4.60^{\mathrm{g}}$ \\
V. amygdalina & $78.60^{\mathrm{j}}$ & $2.66^{\mathrm{e}}$ & $0.50^{\mathrm{b}}$ & $2.23^{\mathrm{d}}$ & $3.60^{\mathrm{b}}$ & $12.33^{\mathrm{a}}$ \\
S. nigrum & $88.47^{\mathrm{a}}$ & $3.10^{\mathrm{b}}$ & $0.50^{\mathrm{b}}$ & $4.43^{\mathrm{a}}$ & $2.56^{\mathrm{g}}$ & $2.93^{\mathrm{i}}$ \\
C. crepidioides & $86.70^{\mathrm{c}}$ & $1.76^{\mathrm{h}}$ & $0.40^{\mathrm{d}}$ & $2.03^{\mathrm{e}}$ & $3.03^{\mathrm{e}}$ & $6.10^{\mathrm{f}}$ \\
O. gratissimum & $83.87^{\mathrm{f}}$ & $2.53^{\mathrm{f}}$ & $2.93^{\mathrm{a}}$ & $2.23^{\mathrm{d}}$ & $3.40^{\mathrm{c}}$ & $7.93^{\mathrm{e}}$
\end{tabular}


Chemical and Phytochemical Profile of Some Uncommon Green Leafy Vegetables Consumed

\begin{tabular}{lllllll}
\hline M. esculenta & $84.57^{\mathrm{e}}$ & $2.83^{\mathrm{d}}$ & $0.40^{\mathrm{d}}$ & $2.27^{\mathrm{d}}$ & $3.73^{\mathrm{a}}$ & $6.20^{\mathrm{f}}$ \\
C. esulenta & $80.13^{\mathrm{i}}$ & $2.67^{\mathrm{e}}$ & $0.23^{\mathrm{f}}$ & $2.77^{\mathrm{c}}$ & $3.30^{\mathrm{d}}$ & $10.90^{\mathrm{c}}$ \\
C. sesamoides & $82.83^{\mathrm{g}}$ & $2.33^{\mathrm{g}}$ & $0.43^{\mathrm{cd}}$ & $2.07^{\mathrm{e}}$ & $2.93^{\mathrm{ef}}$ & $9.40^{\mathrm{d}}$ \\
B. pinnata & $85.53^{\mathrm{d}}$ & $2.57^{\mathrm{f}}$ & $0.30^{\mathrm{e}}$ & $2.90^{\mathrm{b}}$ & $3.27^{\mathrm{d}}$ & $4.37^{\mathrm{g}}$ \\
\hline
\end{tabular}

Sample means followed by the same letters in the vertical line are not significantly different at $\mathrm{P}<0.05$

Table 3.0. Mean values of the mineral composition of leafy vegetables analysed

\begin{tabular}{lcccc}
\hline Samples & $\mathrm{Ca}^{2+}(\mathrm{mg} / \mathrm{kg})$ & $\mathrm{Fe}^{2+}(\mathrm{mg} / \mathrm{kg})$ & $\mathrm{mg}^{2+}(\mathrm{mg} / \mathrm{kg})$ & $\mathrm{PO}_{4}{ }^{2-}(\mathrm{mg} / \mathrm{kg})$ \\
\hline L. taraxacifolia & $120.70^{\mathrm{h}}$ & $5.26^{\mathrm{i}}$ & $3.40^{\mathrm{g}}$ & $75.66^{\mathrm{c}}$ \\
S. sparaganophora & $98.00^{\mathrm{i}}$ & $7.03^{\mathrm{b}}$ & $2.63^{\mathrm{i}}$ & $62.00^{\mathrm{f}}$ \\
C. aconitifolina & $145.30^{\mathrm{e}}$ & $3.80^{\mathrm{h}}$ & $4.10^{\mathrm{c}}$ & $49.33^{\mathrm{g}}$ \\
V. amygdalina & $86.67^{\mathrm{k}}$ & $5.66^{\mathrm{e}}$ & $2.66^{\mathrm{i}}$ & $33.66^{\mathrm{k}}$ \\
S. nigrum & $129.30^{\mathrm{f}}$ & $7.50^{\mathrm{a}}$ & $3.23^{\mathrm{h}}$ & $64.33^{\mathrm{e}}$ \\
C. crepidioides & $121.30^{\mathrm{g}}$ & $6.06^{\mathrm{d}}$ & $2.33^{\mathrm{j}}$ & $34.66^{\mathrm{j}}$ \\
O. gratissimum & $89.33^{\mathrm{j}}$ & $4.20^{\mathrm{g}}$ & $3.90^{\mathrm{e}}$ & $43.33^{\mathrm{i}}$ \\
M. esculenta & $149.33^{\mathrm{d}}$ & $2.50^{\mathrm{i}}$ & $3.60^{\mathrm{f}}$ & $86.00^{\mathrm{b}}$ \\
C. esulenta & $159.33^{\mathrm{b}}$ & $6.63^{\mathrm{c}}$ & $5.23^{\mathrm{a}}$ & $69.00^{\mathrm{d}}$ \\
C. sesamoides & $187.33^{\mathrm{a}}$ & $5.23^{\mathrm{f}}$ & $4.23^{\mathrm{b}}$ & $115.67^{\mathrm{a}}$ \\
B. pinnata & $151.67^{\mathrm{c}}$ & $7.13^{\mathrm{b}}$ & $4.00^{\mathrm{d}}$ & $47.00^{\mathrm{h}}$ \\
\hline S. & &
\end{tabular}

Sample means followed by the same letters in the vertical line are not significantly different at $\mathrm{P}<0.05$

Table 4.0. Mean values of the phytochemical composition of leafy vegetables analysed

\begin{tabular}{lccc}
\hline Samples & Tannins $(\mathrm{mg} / \mathrm{kg})$ & Alkaloids $(\mathrm{mg} / \mathrm{kg})$ & Flavonoids $(\mathrm{mg} / \mathrm{kg})$ \\
\hline L. taraxacifolia & $11.00^{\mathrm{fg}}$ & $9.06^{\mathrm{f}}$ & $22.06^{\mathrm{g}}$ \\
S. sparaganophora & $11.00^{\mathrm{fg}}$ & $13.00^{\mathrm{b}}$ & $21.03^{\mathrm{h}}$ \\
C. aconitifolina & $18.00^{\mathrm{b}}$ & $13.83^{\mathrm{a}}$ & $12.53^{\mathrm{k}}$ \\
V. amygdalina & $13.50^{\mathrm{e}}$ & $10.23^{\mathrm{d}}$ & $26.00^{\mathrm{c}}$ \\
S. nigrum & $10.50^{\mathrm{g}}$ & $9.10^{\mathrm{f}}$ & $29.00^{\mathrm{b}}$ \\
C. crepidioides & $39.00^{\mathrm{a}}$ & $6.50^{\mathrm{h}}$ & $25.00^{\mathrm{d}}$ \\
O. gratissimum & $13.50^{\mathrm{e}}$ & $7.13^{\mathrm{g}}$ & $13.00^{\mathrm{j}}$ \\
M. esculenta & $11.50^{\mathrm{f}}$ & $12.33^{\mathrm{c}}$ & $24.67^{\mathrm{e}}$ \\
C. esulenta & $16.67^{\mathrm{d}}$ & $10.13^{\mathrm{d}}$ & $16.67^{\mathrm{i}}$ \\
C. sesamoides & $17.83^{\mathrm{c}}$ & $10.33^{\mathrm{d}}$ & $35.33^{\mathrm{a}}$ \\
B. pinnata & $8.33^{\mathrm{h}}$ & $9.47^{\mathrm{e}}$ & $22.33^{\mathrm{f}}$ \\
\hline Sample & &
\end{tabular}

Sample means followed by the same letters in the vertical line are not significantly different at $\mathrm{P}<0.05$

The four minerals tested for were all detectable in each of the green leafy vegetables. Cerathoteca sesamoides had the highest calcium content with $187.33 \mathrm{mg} / \mathrm{kg}$ and Solanum nigrum had the highest Iron content $7.5 \mathrm{mg} / \mathrm{kg}$ (Fig .3). Magnesium and phosphate was detected most in Colocassia esulenta $(5.23 \mathrm{mg} / \mathrm{kg}$ ) and Cerathoteca sesamoides $(115.67 \mathrm{mg} / \mathrm{kg}$ ) respectively, while the same mineral contents was lowest in Crassocephalum crepidioides $(2.33 \mathrm{mg} / \mathrm{kg}$ ) and Vernonia amygdalina $(33.66 \mathrm{mg} / \mathrm{kg})($ Table 3$)$.

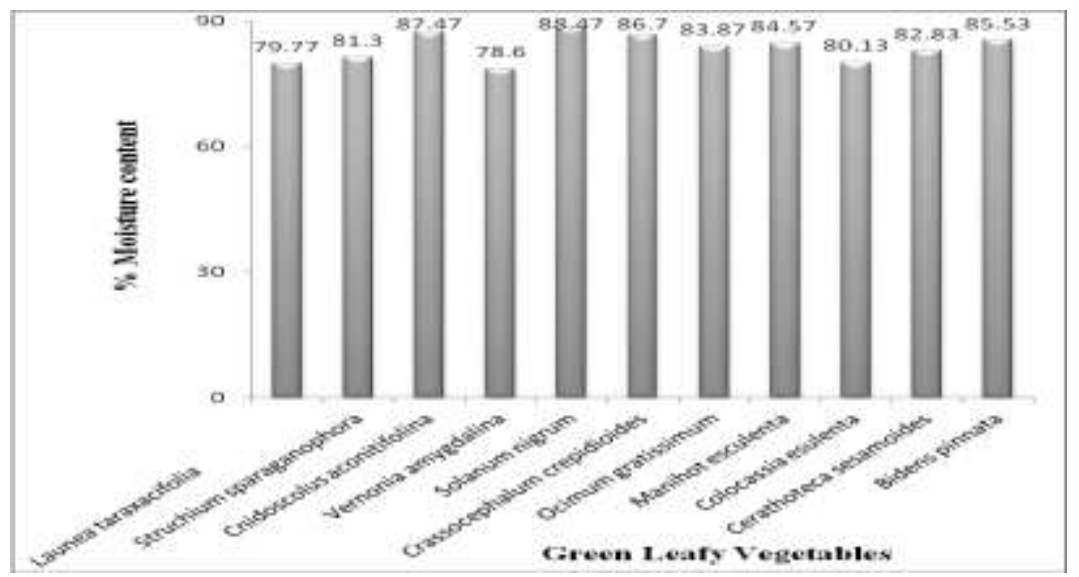

Fig. 1: Moisture content (\%) of some uncommonly consumed green leafy vegetables in south west Nigeria. 


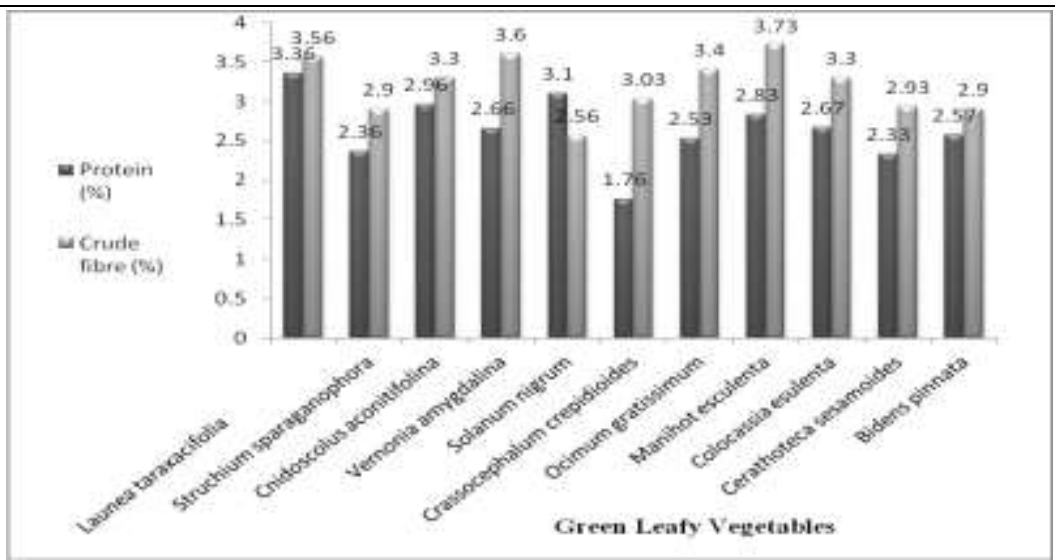

Fig. 2: Protein and Crude fibre content $(\%)$ of some uncommonly consumed green leafy vegetables in south west Nigeria.

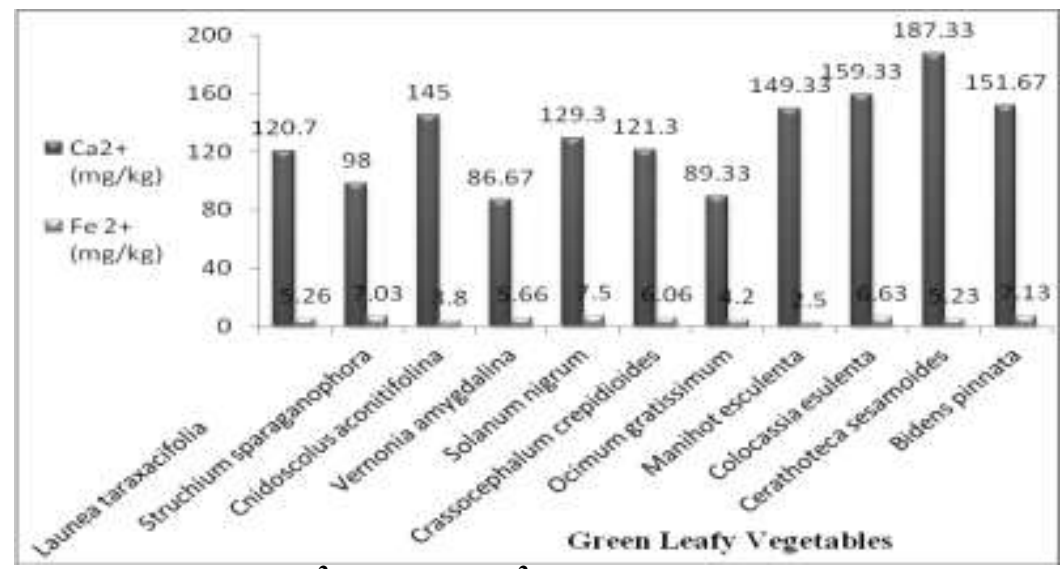

Fig. 3: Calcium $\mathrm{Ca}^{2+}$ and Iron $\mathrm{Fe}^{2+}$ content (mg/kg) of some uncommonly consumed green leafy vegetables in south west Nigeria.

The three phytochemicals tested for were tannins, alkaloids and flavonoids. Overall, flavonoids appeared to be in greater quantity in each of the leafy vegetables sampled when compared to tannins and alkaloids (Table 4). Crassocephalum crepidioides (39mg/kg) (Fig. 4), Cnidoscolus aconitifolina (13.83mg/kg) and Cerathoteca sesamoides $(35.33 \mathrm{mg} / \mathrm{kg}$ ) have the highest content of tannin, alkaloids and flavonoids respectively. Meanwhile, Bidens pinnata (8.33mg/kg) (Fig. 4), Crassocephalum crepidioides $(6.50 \mathrm{mg} / \mathrm{kg}$ ) and Cnidoscolus aconitifolina $(12.53 \mathrm{mg} / \mathrm{kg})$ all have the least content of tannin, alkaloids and flavonoids respectively (Table 4). All the green leafy vegetables analysed are significantly different $(\mathrm{p}<0.05)$ across each chemical and phytochemical compositions (Table 2, 3 and 4).

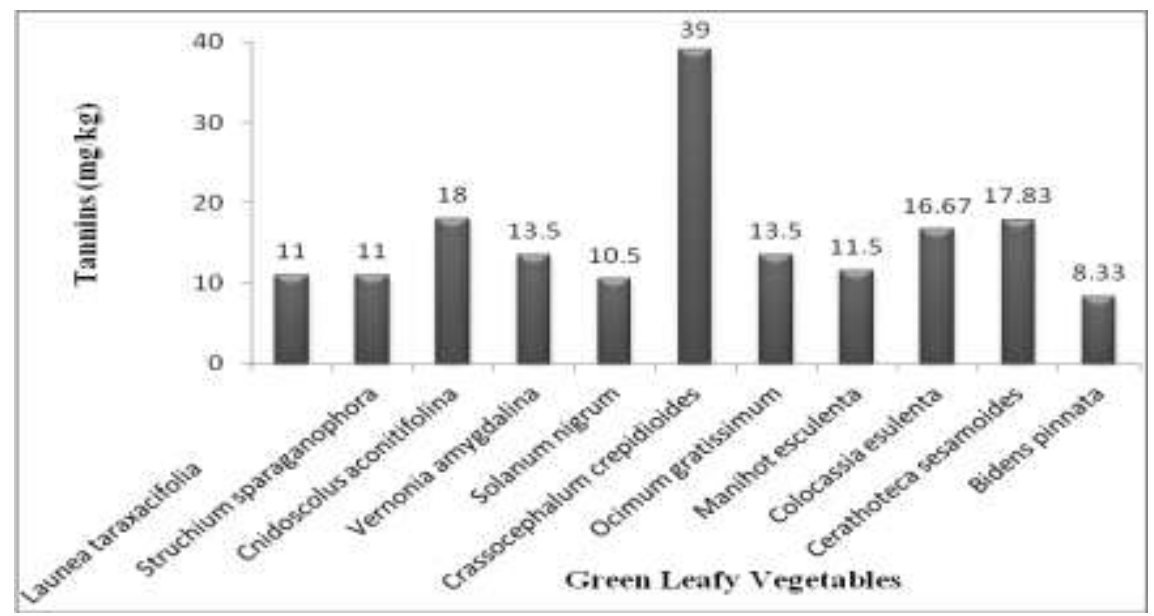

Fig. 4: Tannin content (mg/kg) of some uncommonly consumed green leafy vegetables in south west Nigeria. 


\section{Discussion}

Generally, the vegetables have high moisture content (Table 2) ranging from $88.47 \%$ Solanium nigrum (Odu) to $78.60 \%$ for Vernonia amygdalina (Ewuro). This corresponds to the report that water is the most abundant component in all vegetables [10]. Launea taraxacifolia "Yanrin" had the highest protein content $3.36 \%$ while Crassocephalum crepidioides "Ebolo" had the lowest protein content $1.76 \%$.

All the vegetable samples have a low fat content. The ether extracts ranges from $0.56 \%$ for Vernonia amygdalina (Ewuro) to $0.20 \%$ for Cnidoscolus aconitifolina "Iyana Ipaja". The ash content ranged from 4.43 to $1.73 \%$ for S. nigrum and C. aconitifolina respectively. The high fibre content of vegetables has been shown to be essential in enhancing gastrointestinal functions, prevents constipation and prevents intake of excess starchy food [2,4]. All the vegetables have high fibre component from 3.73\% for Manihot esculenta "ewe ege" to $2.56 \%$ for Solanum nigrum "Odu". The carbohydrate contents ranged from $12.33 \%$ Vernonia amygdalina "Ewuro" to $2.93 \%$ in Solanum nigrum "Odu".

All the vegetable samples were high in calcium (Table 3) with Cerathoteca sesamoides having the highest calcium content $(187.33 \mathrm{mg} / \mathrm{kg}$ ) and Vernonia amygdalina "Ewuro" had the lowest calcium content $(88.67 \mathrm{mg} / \mathrm{kg})$. There was a significant difference $(\mathrm{P}<0.05)$ in the calcium content among the eleven samples analysed. Calcium is a major factor for sustaining strong bones and plays a part in muscle contraction and relaxation, blood clotting, synaptic transmission and absorption of vitamin $\mathrm{B}_{12}$ [2,12]. $\mathrm{For} \mathrm{Fe}^{++}$, (iron), not all the vegetables were high in iron, Solanum nigrum "Odu" had highest with $7.5 \mathrm{mg} / \mathrm{kg}$ to Manihot esculenta "ewe ege" $(2.50 \mathrm{mg} / \mathrm{kg})$. This shows that these samples contain iron needed in haemoglobin formation $[4,11]$. Green leafy vegetables are recommended for anemic convalescence. Magnesium contents ranged from $2.33 \mathrm{~kg} / \mathrm{mg}$ for Crassocephalum crepidioides "Ebolo" to $5.23 \mathrm{mg} / \mathrm{kg}$ for Colocassia esulenta "ewe koko". Magnesium is good for human health as it is known to reduce blood pressure [4,11].

Tannin contents of all the vegetable samples were significantly different at $(\mathrm{P}<0.05)$ from each other. Crassocephalum crepidioides "Ebolo" had highest value for tannin $39.00 \mathrm{mg} / \mathrm{kg}$. With the exception of tea, long term and/or excessive use of herbs containing high concentration of tannins is not recommended [4]. A correlation has been made between oesophageal or nasal cancer in humans and regular consumption of certain herbs with high tannin concentrations [2,7,12]. However, consumption of vegetables with moderate concentration of tannin is good for human health $[2,12]$. Total alkaloid was highest in Cnidoscolus aconitifolina "Iyana Ipaja" $13.83 \mathrm{mg} / \mathrm{kg}$ while Crassocephalum crepidioides "Ebolo" the lowest concentration of Alkaloid with $6.50 \mathrm{mg} / \mathrm{kg}$ (Table 4). Generally, alkaloids have specific effects on the central nervous system (for example, caffeine), especially on the synapses (the gaps between nerve cells) in the conduits of the nervous system. The universal solubility of alkaloids in lipids is pertinent in this type of exploits [12]. Table 4 also shows that Cerathoteca sesamoides "Ekuku" is rich in flavonoid.

The green leafy vegetables were significantly different $(\mathrm{p}<0.05)$ in their chemical and phytochemical compositions.

\section{Conclusion}

Overall, the result shows that the vegetable samples analysed are good sources of both essential nutrients and phytochemicals. However, it is recommended that further work could be carried out to ascertain the effect of blanching on the nutritional and phytochemical composition of these vegetable samples at various temperatures and time. Since, in south west Nigeria, vegetable are mostly consumed blanched or cooked.

\section{References}

[1] O.A. Edema, Production of some common vegetables. (Horticultural Research Institute Ibadan, 1987).

[2] J.K. Mensah, R.I. Okoli and J.O. Obaju-Obodo, Phytochemical, medicinal and nutritional properties of some green leafy vegetables. Afr. J. Biotechnol. 2512 (12): 2008, 758.

[3] N.A. Mnzava, Comparing nutritional values of exotic and indigenous vegetables. In: Processing of a workshop on indigenous vegetable. Limbe Cameroon, January 1997. R.R. Schippers, L. Budd, (eds) (Chattam. U.K; NRI/IPGR/CPRO workshop, 1997).

[4] A.O. Fasuyi, Nutritional potential of some tropical vegetable leaf meals. Chemical characteristics and functional properties. Afri. J. Biotechnol. 5 (1): 2006, $49-53$.

[5] J.C. Okafor, Horticulturally promising indigenous wild plants species of the Nigerian Forest Zone Acts Horticulture. 123: 1983, 165 $-177$.

[6] M.V.A. Alta and O.A. Adeogun, Nutrient components of some tropical leafy vegetables. J. Food Chem. 53: 1995, 375-379.

[7] G. Williamson, M.S. Dupont, R.K. Heaney, G. Roger and M.J. Rhodes, Induction of slutathione S transferase activity in hepG2 cells by extracts of fruits and vegetables. J. Food Chem. 2: 1997, 157-160.

[8] R.H. Liu, Potential synergy of phytochemicals in cancer prevention: mechanism of action. J. Nutr. 134: 2004, 34795-34855.

[9] AOAC, Association of Official Analytical Chemists. Official method of Analysis (18th edition). (AOAC Intl., USA. 2006).

[10] P.O. Fayemi, Nigerian Vegetables. (Heins educational book, Ibadan, Nigeria. 1999).

[11] G.O. Latunde-Dada, Effect of processing on iron level and availability from Nigeria vegetables. J. Sci. Food Agric. 53: 1990, 355361

[12] W.M. Lewis, and M.P.F. Elvin-Lewis, "Plants affecting man's Health” Medical botany (John Wiley and sons, 1998). 